Dhaka Univ. J. Biol. Sci. 31(1): 29-43, 2022 (January) ～DOI: https://doi.org/10.3329/dujbs.v31i1.57914

\title{
ASSESSMENT OF ENVIRONMENTAL QUALITY OF AN AREA ADJACENT TO THE RELOCATED TANNERY INUSTRIES AT HEMAYETPUR, BANGLADESH
}

\author{
Md Wahiduzzaman*, Md Faruque Hossain ${ }^{1}$ and Zakia Parveen \\ Department of Soil, Water and Environment, University of Dhaka, \\ Dhaka-1000, Bangladesh
}

Key words: Tannery wastes, Environmental quality, Nutrients, Physicochemical properties

\begin{abstract}
The deterioration of environmental quality due to wastes generated from tannery industries is an alarming global issue in Bangladesh. To assess this problem in an area adjacent to the recently shifted tannery industries at Hemayetpur, soil, water and plant samples are collected from upstream as control, secondary treatment ponds, main discharge station and downstream at 500, 1000, 2000 and $3000 \mathrm{~m}$ across the areas and are analyzed for environmental quality. The water samples of Dhaleswari river are slightly acidic to moderately alkaline $\mathrm{pH}$ from 6.55 to 10.60, high TDS from 176 to $10,433 \mathrm{mg}$, EC from 305 to $18,206 \mu \mathrm{S} / \mathrm{cm}$, nitrate from 0.14 to $194 \mathrm{mg}$, sulfate from 10.72 to $8922 \mathrm{mg} \Lambda$, moderate phosphate from 0.58 to $7.2 \mathrm{mg} /$ and low DO from 1.61 to $5.50 \mathrm{mg} /$. It is clearly noticed that most of the water parameters exceeded WHO guideline values except $\mathrm{pH}$ and phosphate that indicates Dhaleswari river water quality is declining slowly. The available concentrations of nitrogen, phosphorus, potassium and sulfur in soil varies from 12 to $263,1.19$ to 38,17 to 170,251 to 680 $\mathrm{mg} / \mathrm{kg}$, respectively, whereas, the total concentration ranges from 0.03 to $0.14 \%$, 0.090 to $0.14 \%, 0.12$ to $0.48 \%$, and 0.11 to $0.42 \%$, respectively. In soil samples, total phosphorus and potassium concentrations are increased but sulfur decreased. The soils are found acidic in nature that have high EC $8.17 \mathrm{dS} / \mathrm{m}$. A significant positive correlation is found with each other of nitrogen, phosphorus, potassium and sulfur concentrations in soil samples. The nutrients in plant samples have no deficiency those are within the optimum range.
\end{abstract}

\section{Introduction}

The tannery industries of Bangladesh play a vital role in national economy since it contributes a large share of export earning every year. Despite this economic importance, the tannery industry is recognized as a major contributor of pollution and poses serious environmental threats worldwide ${ }^{(1)}$. A large amount of liquid and solid wastes like chemical residues and reagents, leather cuttings, trimmings and gross shavings, fleshing residues, solid hair debris, heavy metals, salts, and pathogens are generated from several

*Author for correspondence: <md-2013513032@swe.du.ac.bd>. ${ }^{1}$ American International UniversityBangladesh, Kuratoli Road, Dhaka 1229, Bangladesh. 
stages of leather making process ${ }^{(2-4)}$. These wastes are discharged into natural water bodies directly or indirectly with little or without any treatment, causing deterioration of surface and groundwater quality severely(5-6). The river carries numerous toxins along its flow to downstream and makes the river water unsuitable for domestic and agricultural use $^{(7)}$. In summer, the situation become worsen due to the higher rate of decomposition of the wastes caused by increased microbial activity ${ }^{(8)}$.

Irrigation with this contaminated river water can increase the salinity and sodicity of soil in the surrounding area(9). Cultivated crops and plants around the area being irrigated by the wastewater often receive necessary nutrients from the wastewater. The microbial functioning of the soil can also be threatened by this wastewater(9). The application of tannery effluent to soils of differing textures showed a reduction in rice yield and the effect was more pronounced in light soils compared to heavy soils ${ }^{(10)}$.

Earlier, tannery industries were situated in a heavily populated residential area of Hazaribagh that discharged approximately $21,600 \mathrm{~m}^{2}$ liquid wastes and 150 metric tons of solid waste every day to Buriganga river near Dhaka city(11). To save the Buriganga river from pollution, the Government of Bangladesh shifted the whole industrial set up at Hemayetpur on the bank of Dhaleswari river. Almost 123 tannery factories are currently operating in Savar occupying an area of 200 acres. A central effluent treatment plant (CETP) was installed in the facility to control the pollution and create a well-managed scenario for the leather industry. However, these industries do not run ETP in order to earn extra profit ${ }^{(12)}$. During full-scale operation, effluents overload the canals and CETP area and flood the adjacent land. As a result, untreated effluents get a chance to mix with the Dhaleswari river water. Therefore, this research aimed to evaluate the effect of tannery discharges on the quality of the tannery adjacent river water and to investigate the effects of wastewater irrigation on soil fertility and plant nutrition.

\section{Materials and Methods}

Samples were collected during October 2018 from the surroundings of the tannery industries and the Dhaleswari river at Hemayetpur, Savar which were exposed to different levels of environmental pollution. The sampling site was approximately $15 \mathrm{~km}$ west of the capital city Dhaka. The sampling area lies within the geographic coordinates of $23^{\circ} 47^{\prime} 52.2^{\prime \prime} \mathrm{N}, 90^{\circ} 14^{\prime} 43^{\prime \prime} \mathrm{E}$ to $23^{\circ} 46^{\prime} 0^{\prime \prime} \mathrm{N}, 90^{\circ} 14^{\prime} 12^{\prime \prime} \mathrm{E}$. According to BARC(13), the collected soil sample belonged to the Agro-ecological-zone (AEZ) of Young Brahmaputra and Jamuna flood plain and subregion of Low Jamuna floodplain. Since determining the water quality of the Dhaleswari river along the tannery industry was one of the major objectives, the study area was divided into a pattern where upstream of the river flow was considered as unaffected by tannery industries.

Water samples were collected from eleven points. The Dhaleswari is a tributary river of the river Jamuna and starts from Tangail and at the downstream it meets with 
Narayanganj. The tannery industries fall in the way of the Dhaleswari's downstream flow. Hereby, RW-1 (river water-1) sample represented the point that was $1000 \mathrm{~m}$ ahead of the industrial setup and regarded as the upstream. Other river water (RW) samples were collected based on distance from the discharge points (DP) i.e. RW-2 (100 m from DP), RW-3 (500 m from DP), RW-4 (1000 m from DP), RW-5 (2000 m from DP), RW-6 (3000 $\mathrm{m}$ from DP). Wastewater samples were collected from four points including discharge points (DP-1, DP-2, DP-3) and untreated effluent (UE). Lastly, ground water sample was collected from the nearby shallow tube well located just outside of the industrial compound. Three samples were collected from each point. Water samples were collected in poly-ethylene bottles (washed with detergent then with distilled water followed by $2 \mathrm{M}$ nitric acid, then distilled water again and finally with sampled water). The plastic bottles containing river water and wastewater were preserved by acidification to $\mathrm{pH} \leq 2$ using $10 \%$ nitric acid. After acidification the collected samples were stored at $4^{\circ} \mathrm{C}$ for subsequent use.

The soil samples were collected from the seven points ranging from upstream to $3 \mathrm{~km}$ away from discharge point. Both the topsoil and subsoil were collected except one point which was collected from untreated dumping pond. The top soils were collected from 0 to $15 \mathrm{~cm}$ depth and the subsoils were collected from a depth of 15 to $30 \mathrm{~cm}$. Both the top soils and sub soils were collected using an auger. Three samples from each point were mixed to make a composite sample and taken into a polyethylene bag with appropriate labelling. The collected soil samples were dried in the air for 7 days by spreading in a thin layer on a clean piece of paper. Visible roots and debris were removed from the soil samples. For hastening the drying process, the soil samples were exposed to sunlight. After air-drying, a portion of the larger aggregates were broken by gently crushing them by a wooden hammer. Ground samples were screened to pass through a $2 \mathrm{~mm}$ stainless steel sieve. The sieved samples were then mixed thoroughly. Soil samples were preserved in plastic containers and labelled properly showing the soil number, sample number and date of collection. These soils were used for chemical and physicochemical analyses.

The plant samples were collected from where the soil samples were collected. The collected plant samples were Pennisetum purpureum Schumach (Napier grass), Eichhornia crassipes Mart. (Water hyacinth), Colocasia esculenta (L.) Schott (Taro), Ipomoea aquatica Forssk. (Water spinach) and Cynodon dactylon (L.) Pers. (Scutch grass). The code PSP denoted plant sampling point and CPS as contaminated plant sample. Plant samples were collected fresh from the sampling area in required amounts, wrapped in polyethylene bags and transported to the laboratory and for processing. The roots of the plants were washed first with tap water and then again with distilled water to remove ions from the root free surface as to dislodge any adhering particles on the root surface. Arial portion of the plants were also washed following the same procedure. The wet 
samples were dried by exposing them to the air. The plant samples were separated using scissors into three parts- root, shoot and leaves. The samples were oven dried at $70 \pm 5^{\circ} \mathrm{C}$ for 48 hours. The samples were ground with an electrical grinder and passed through a $0.2 \mathrm{~mm}$ sieve. The individual ground sample was mixed properly and kept in envelop labelling properly and stored in dry place.

Laboratory analyses and analytical procedures: Water analysis was done following the standard methods described in $\mathrm{APHA}^{(14)}$. Soil and water $\mathrm{pH}$ were measured electrochemically with the help of glass electrode $\mathrm{pH}$ meter (HANNA Instrument, model no-HI2211). For determining soil $\mathrm{pH}$, the ratio of soil to water was 1:2.5, as described by Jackson and Alloways(15). The electrical conductivity of soil and water samples were measured using an EC meter (EUTECH Instrument, model no- CON700). The ratio of soil : water during EC measurement was 1:5. The dissolved oxygen (DO) of water samples was determined using a DO meter (HANNA Instrument, model no- HI2400). The total dissolved solids (TDS) of the water samples were measured with the help of a TDS meter (HANNA Instrument, model no- HI2300). Before measurement, all the instruments were calibrated according to the standard protocol.

The soil samples were digested with aqua regia mixture ${ }^{(16)}$. The Plant samples were digested with Nitric and perchloric acid. Total nitrogen concentration was determined by micro kjeldahl's method as described by Bremner and keeney ${ }^{(17)}$. The total phosphorus was determined as described by Jackson and Alloways(15). The available phosphorus in the extract was determined colorimetrically using spectrophotometer (HACH DR5000) at $882 \mathrm{~nm}^{(18)}$. Total potassium and available potassium concentrations were measured by Flame photometer (JENWAY PFP7)(16,19). Total and the available sulfur was determined turbidimetrically using a spectrophotometer (HACH DR5000) at $420 \mathrm{~nm}^{(20-21)}$. The organic carbon of soil samples was determined by wet oxidation method of Walkley and Black ${ }^{(22)}$.

All the data were statistically analyzed using Microsoft Excel and Minitab-17 software following correlation study and presented in Table 1 and text form.

\section{Results and Discussion}

Electrical conductivity (EC) and $\mathrm{pH}$ indicate salinity and acidity respectively, whereas DO and TDS shows the organic load in the water samples. Studied water and effluent samples had a $\mathrm{pH}$ ranges from very slightly acidic to alkaline i.e., 6.55 to 10.60 (Table 2). The maximum pH was noticed in DP-1 (10.60) which might be due to the presence of carbonates and bicarbonates ${ }^{(23)}$. Similar results were recorded by Asghar et al.(24) in wastewater samples of Lahore, Pakistan. In Kanpur, India Parveen et al.(23) found the $\mathrm{pH}$ ranged between 9.15-10.05 in water samples of tannery industrial area, which were different from this finding on an average. The EC and TDS values of the water samples ranged from 305 to $18207 \mu \mathrm{S} / \mathrm{cm}$ and 176 to $10433 \mathrm{mg} /$, respectively (Table 2). The highest readings for both EC and TDS were found in the point UE, which was the 


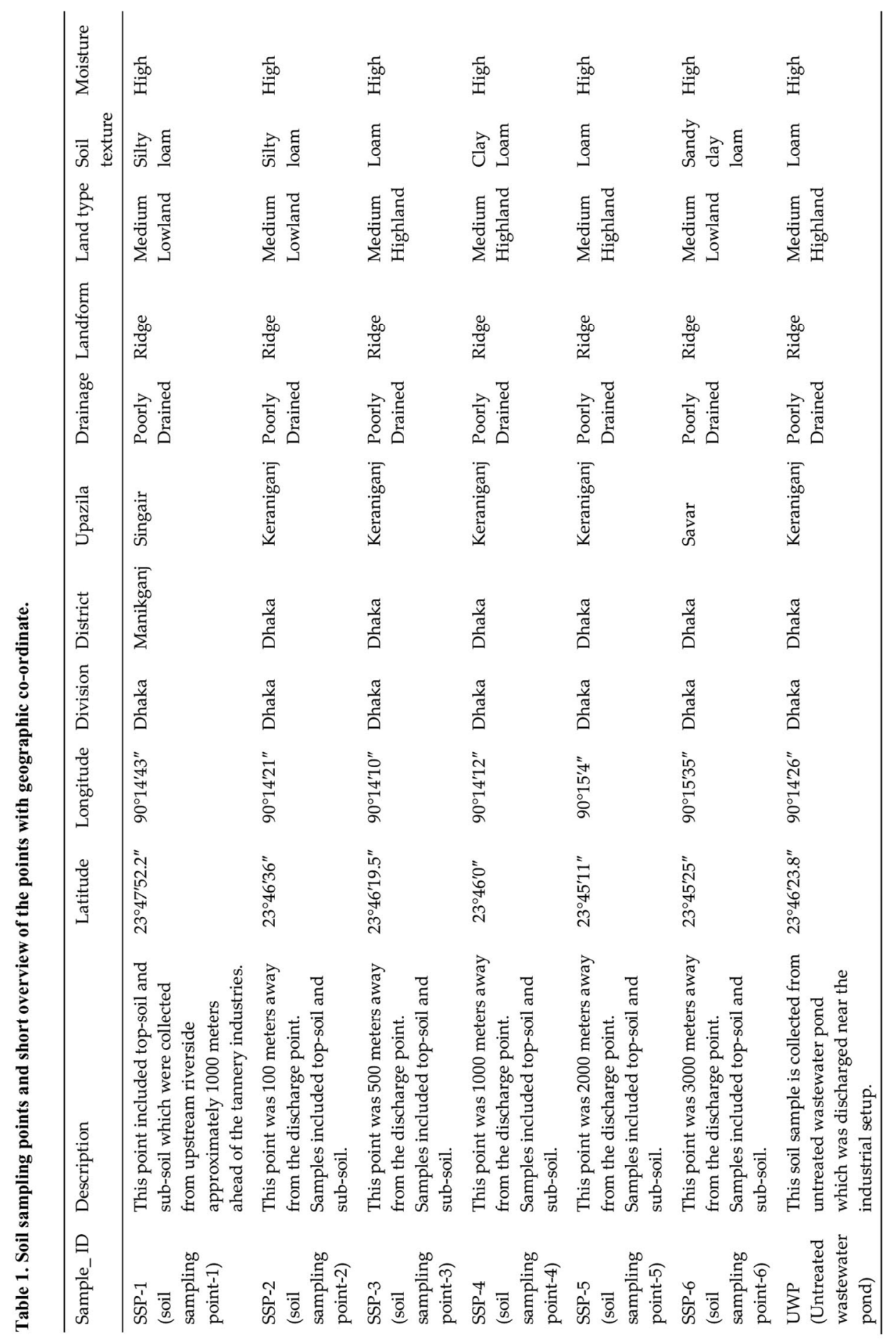


untreated tannery effluent. However, TDS in other wastewater samples (DP-1, DP-2, DP3) showed similar kind of findings and exceeded the limit (1000 $\mathrm{mg} /$ ) provided by $\mathrm{WHO}^{(25)}$. However, river waters (RW-1-RW-6) exhibited lower concentration which were within the permissible limit. Murali et al.(26) observed similar results of higher conductivity in treated and untreated tannery effluent. Hoque and Deb(27) reported a higher level of EC (604 to $1101 \mu \mathrm{S} / \mathrm{cm}$ ) and TDS (112 to $587 \mathrm{mg} /$ ) in tannery effluent contaminated water of the Buriganga river as well. The DO of the studied samples ranged from 1.61 to $5.50 \mathrm{mg} /$. The discharge points (DP-1, DP-2, DP-3) had very low DO level as well, which was below the standard limit of $4.5-8^{(25)}$. Siddiqee et al.(28) found similar kind of results in tannery industrial area of Hazaribagh.

Table 2. Physicochemical properties of water samples collected from different sampling points.

\begin{tabular}{lcccccccc}
\hline \multirow{2}{*}{$\begin{array}{l}\text { Denota- } \\
\text { tion }\end{array}$} & \multicolumn{7}{c}{ Properties of water $(\mathrm{mg} /)$} \\
\cline { 2 - 9 } & $\mathrm{pH}$ & $\mathrm{EC}(\mathrm{\mu S} / \mathrm{cm})$ & $\mathrm{TDS}$ & $\mathrm{DO}$ & $\mathrm{PO}_{4}{ }^{--}$ & $\mathrm{SO}_{4}{ }^{--}$ & $\mathrm{NO}_{3}{ }^{-}$ & $\mathrm{K}^{+}$ \\
\hline RW-1 & 7.26 & 305 & 176 & 5.70 & 0.92 & 22.22 & 2.54 & 8.86 \\
GW & 6.93 & 701 & 402 & 5.91 & 1.14 & 10.72 & 0.24 & 2.03 \\
DP-1 & 10.60 & 8557 & 4977 & 1.74 & 4.05 & 1968 & 95.15 & 17.53 \\
DP-2 & 6.55 & 15850 & 9270 & 2.08 & 7.28 & 8922 & 152 & 46.69 \\
DP-3 & 7.53 & 4747 & 2710 & 2.10 & 1.87 & 83.32 & 24.58 & 9.53 \\
UE & 7.07 & 18207 & 10433 & 1.61 & 4.08 & 8404 & 194 & 27.03 \\
RW-2 & 7.35 & 403 & 226 & 5.21 & 1.74 & 72.80 & 35.15 & 3.19 \\
RW-3 & 7.23 & 406 & 229 & 3.40 & 1.01 & 14.76 & 15.83 & 1.86 \\
RW-4 & 7.22 & 383 & 216 & 3.35 & 1.04 & 11.80 & 7.28 & 1.69 \\
RW-5 & 7.25 & 379 & 215 & 3.84 & 1.04 & 14.49 & 5.31 & 2.53 \\
RW-6 & 7.14 & 359 & 204 & 3.42 & 1.06 & 12.93 & 5.35 & 1.86 \\
MPL ${ }^{a}$ & $5.5-9.0$ & 1200 & 1000 & $4.5-8.0$ & 5 & 400 & 10 & 12 \\
\hline
\end{tabular}

a Maximum permissible limit by $\mathrm{WHO}^{(25)}$

Nitrate concentrations of the water samples are found in the range of 0.24 to 194.07 $\mathrm{mg} 1$. The discharge point shows very high concentrations of nitrate. Among the riverwater samples, the points which are $100 \mathrm{~m}$ and $500 \mathrm{~m}$ away from the discharge points crossed the maximum permissible limit of $10 \mathrm{mg} \Lambda^{(25)}$. Bhuiyan et al..$^{(1)}$ found similar kind of results ranged from 2.67 to $177 \mathrm{mg} /$. The phosphate and sulphate concentrations in the water samples ranged from 0.98 to $7.20 \mathrm{mg} \Lambda$ and 10.72 to $8922 \mathrm{mg} \Lambda$, respectively. The highest concentrations of sulfate and nitrate were observed for DP-2. The sulfur concentration in this sampling point (DP-2) exceeded the standard limit (400 $\mathrm{mg} \Lambda$ ) provided by $\mathrm{WHO}^{(25)}$. Compared to the present study Kaushik et al.(29) reported a lower 
phosphate ( 0.002 to $0.52 \mathrm{mg} \Lambda$ ) and similar sulfate $(14.20$ to $53.40 \mathrm{mg} \Lambda)$ concentrations in Yamuna river, India which was contaminated by tannery effluent on the other hand, Gutterres et al. ${ }^{(30)}$ noted an elevated level of Phosphate concentration ranged from 15-83 $\mathrm{mg} /$ in the tannery wastewater. The discharge points (DP-1, DP-2, DP-3) showed higher concentration of potassium than the recommended level of WHO, however in the Dhaleswari river water samples potassium concentrations were within the limit.

Physicochemical characteristics of the soil samples: The $\mathrm{pH}$ of the studied soil samples ranged from 4.9 to 8.15 in the top-soils and 5.65 to 8.10 in the subsoils (Table 3). The lowest $\mathrm{pH} 4.5$ is found in the top-soil of SSP-3. The acidic $\mathrm{pH}$ might reflect the abundance of organic wastes and the evolution of $\mathrm{CO}_{2}$ around the area( ${ }^{(31)}$. Sahu et al.(5) and AlvarezBernal et al.(9) found tannery wastewater contaminated soil $\mathrm{pH}$ in the range of 7.50 to 8.24 and 6.2 to 6.6 , respectively. The EC value of soil samples ranged from 1.44 to 8.17 in the top-soils and 0.63 to 2.47 in the sub-soils (Table 3). The high EC might be due to higher amounts of soluble $\mathrm{Na}, \mathrm{Mg}^{(11)}$. Electric conductivity value above $4 \mathrm{dS} / \mathrm{m}$ is harmful for plant growth ${ }^{(32)}$ and similar level of EC reported by Alvarez-Bernal et al. in tannery effluent contaminated soil samples in Guanajuato, Mexico(9). The level of organic carbon

Table 3. Physicochemical properties and organic carbon of studied soil samples in and around the tannery industries of Hemayetpur area.

\begin{tabular}{llccc}
\hline Denotation & Type of samples & $\mathrm{pH}$ & $\begin{array}{c}\mathrm{EC} \\
(\mathrm{dS} / \mathrm{m})\end{array}$ & $\begin{array}{c}\text { Organic carbon } \\
(\%)\end{array}$ \\
\hline SSP-1 & Topsoil & $6.50 \pm 0.00$ & $1.59 \pm 0.01$ & $1.20 \pm 0.09$ \\
& Subsoil & $7.40 \pm 0.00$ & $0.65 \pm 0.01$ & $0.62 \pm 0.00$ \\
SSP-2 & Topsoil & $6.72 \pm 0.03$ & $2.10 \pm 0.07$ & $1.40 \pm 0.00$ \\
& Subsoil & $5.65 \pm 0.07$ & $0.63 \pm 0.02$ & $1.27 \pm 0.05$ \\
SSP-3 & Topsoil & $4.90 \pm 0.00$ & $2.47 \pm 0.07$ & $1.10 \pm 0.00$ \\
& Subsoil & $6.10 \pm 0.00$ & $0.74 \pm 0.05$ & $0.47 \pm 0.16$ \\
SSP-4 & Topsoil & $8.15 \pm 0.07$ & $1.44 \pm 0.03$ & $0.68 \pm 0.31$ \\
& Subsoil & $8.10 \pm 0.14$ & $0.68 \pm 0.01$ & $0.31 \pm 0.00$ \\
SSP-5 & Topsoil & $4.83 \pm 0.04$ & $2.07 \pm 0.04$ & $1.25 \pm 0.08$ \\
& Subsoil & $6.28 \pm 0.04$ & $0.98 \pm 0.02$ & $0.65 \pm 0.05$ \\
SSP-6 & Topsoil & $6.23 \pm 0.04$ & $7.30 \pm 0.23$ & $1.22 \pm 0.05$ \\
& Subsoil & $6.55 \pm 0.07$ & $2.47 \pm 0.07$ & $0.83 \pm 0.09$ \\
UWP & Topsoil & $7.70 \pm 0.14$ & $8.17 \pm 0.04$ & $0.78 \pm 0.00$ \\
\hline
\end{tabular}


analyzed in the studied soil samples ranged from 0.68 to $1.40 \%$ in the top-soil and $0.31 \%$ to $1.27 \%$ in the sub-soil. The percentage was within the level as reported for agricultural soils(33). Mondol et al.(11) found a higher percentage of organic carbon in soils of Hazaribagh tannery industrial area.

Nutrient concentrations of the collected soil samples: The available nitrogen of top-soils ranged from 25.67 to $263.67 \mathrm{mg} / \mathrm{kg}$ in the top-soil and 11.67 to $77.00 \mathrm{mg} / \mathrm{kg}$ in the sub-soil (Table 4). The maximum availability in top-soil was observed in the UWP (263.67 mg/kg) which was collected from untreated wastewater pond. This high Nitrogen concentration in UWP sample indicated the presence of high organic wastes dumped in that pond. Whereas the maximum concentration in sub-soil was observed in SSP-5 (77 mg/kg), which might be due to a higher rate of leaching. An earlier study found a higher concentration of nitrogen in Hazaribagh tannery industrial area which ranged from 92 to $960 \mathrm{mg} / \mathrm{kg}^{(11)}$.

Table 4. Concentrations of available and total N, P, K, S of the studied soil samples around the Hemayetpur area.

\begin{tabular}{|c|c|c|c|c|c|c|c|c|c|}
\hline \multirow{3}{*}{$\begin{array}{l}\text { Denota- } \\
\text { tion }\end{array}$} & \multirow{3}{*}{$\begin{array}{l}\text { Soil } \\
\text { type }\end{array}$} & \multicolumn{8}{|c|}{ Major nutrients } \\
\hline & & \multicolumn{2}{|c|}{ Nitrogen } & \multicolumn{2}{|c|}{ Potassium } & \multicolumn{2}{|c|}{ Phosphorus } & \multicolumn{2}{|c|}{ Sulfur } \\
\hline & & $\begin{array}{l}\text { Avail. N } \\
(\mathrm{mg} / \mathrm{kg})\end{array}$ & $\begin{array}{l}\text { Total } \\
(\% \mathrm{~N})\end{array}$ & $\begin{array}{l}\text { Avail. K } \\
(\mathrm{mg} / \mathrm{kg})\end{array}$ & $\begin{array}{l}\text { Total } \\
(\% \mathrm{~K})\end{array}$ & $\begin{array}{l}\text { Avail. P } \\
(\mathrm{mg} / \mathrm{kg})\end{array}$ & $\begin{array}{l}\text { Total } \\
(\% \mathrm{P})\end{array}$ & $\begin{array}{l}\text { Avail. S } \\
(\mathrm{mg} / \mathrm{kg})\end{array}$ & $\begin{array}{l}\text { Total } \\
(\% \mathrm{~S})\end{array}$ \\
\hline \multirow[t]{2}{*}{ SSP-1 } & Topsoil & 44.33 & 0.09 & 60.35 & 0.42 & 2.54 & 0.14 & 44.78 & 0.14 \\
\hline & Subsoil & 21.00 & 0.04 & 17.02 & 0.23 & 18.78 & 0.08 & 21.00 & 0.11 \\
\hline \multirow[t]{2}{*}{ SSP-2 } & Topsoil & 25.67 & 0.08 & 17.02 & 0.24 & 3.97 & 0.11 & 15.65 & 0.08 \\
\hline & Subsoil & 42.00 & 0.11 & 37.02 & 0.33 & 2.05 & 0.09 & 44.00 & 0.41 \\
\hline \multirow[t]{2}{*}{ SSP-3 } & Topsoil & 109.67 & 0.14 & 13.68 & 0.19 & 1.19 & 0.13 & 24.80 & 0.40 \\
\hline & Subsoil & 46.67 & 0.06 & 67.02 & 0.11 & 1.30 & 0.19 & 34.29 & 0.12 \\
\hline \multirow[t]{2}{*}{ SSP-4 } & Topsoil & 25.67 & 0.06 & 20.35 & 0.11 & 17.15 & 0.10 & 41.88 & 0.16 \\
\hline & Subsoil & 11.67 & 0.03 & 20.35 & 0.40 & 16.47 & 0.13 & 15.42 & 0.11 \\
\hline \multirow[t]{2}{*}{ SSP-5 } & Topsoil & 35.00 & 0.14 & 60.35 & 0.23 & 3.04 & 0.09 & 32.61 & 0.21 \\
\hline & Subsoil & 77.00 & 0.07 & 37.02 & 0.19 & 5.05 & 0.13 & 12.75 & 0.20 \\
\hline \multirow[t]{2}{*}{ SSP-6 } & Topsoil & 100.33 & 0.10 & 170.35 & 0.47 & 2.85 & 0.14 & 28.59 & 0.31 \\
\hline & Subsoil & 49.00 & 0.07 & 50.35 & 0.26 & 4.36 & 0.15 & 63.53 & 0.10 \\
\hline UWP & Topsoil & 263.67 & 0.13 & 50.35 & 0.29 & 37.57 & 0.09 & 34.17 & 0.87 \\
\hline
\end{tabular}

Results in Table 4 reflected that the available $\mathrm{P}$ concentration in topsoil ranged from 1.19 to 37.57 and 1.30 to $16.47 \mathrm{mg} / \mathrm{kg}$ in the sub-soil. This variable level of available phosphorus concentrations might be due to the different extraction methods and soil $\mathrm{pH}$. 
The optimum range of available phosphorus was 15.76 to $21.0 \mathrm{mg} / \mathrm{kg}^{(34)}$. The analyzed available phosphorus concentration was lower in most of the samples. Mondol et al.(11) recorded available phosphorus concentration of 2.4 to $7.2 \mathrm{mg} / \mathrm{kg}$ in the Hazaribagh area, which was lower than this finding.

The concentrations of available potassium in studied soil samples ranged from 17.02 to $50.35 \mathrm{mg} / \mathrm{kg}$ in sub-soil and 17.02 to $170.35 \mathrm{mg} / \mathrm{kg}$ in top-soil (Table 4). The critical limit of available $\mathrm{K}$ in soil is $31.6 \mathrm{mg} / \mathrm{kg}^{(34)}$. Some of the studied soil samples concentrations were below the critical limit, which indicated deficiency in potassium. Mondol et al.(11) found a higher concentration of potassium in the Hazaribagh area and it varied from 16 to $245 \mathrm{mg} / \mathrm{kg}$. The concentration of available sulfur in studied soil samples varied from 251.13 to $680.38 \mathrm{mg} / \mathrm{kg}$ in sub-soil and 104.38 to $497.36 \mathrm{mg} / \mathrm{kg}$ in top-soil (Table 4). The higher concentration might be due to the salts used in tanning process ${ }^{(31)}$. The concentrations were very high from the optimum level which might cause toxicity for plants. The total nitrogen in the top-soil ranged from 0.0621 to $0.147 \%$ and 0.030 to $0.119 \%$ in the sub-soil (Table 4). The highest total N was found in the SSP-5 $(0.147 \%)$ and the lowest was found in the SSP-4 $(0.030 \%)$. The results have well agreement with the findings obtained by Alvarez-Bernal et al. in tannery contaminated soils of Leon, Mexico(9) whereas, in Hazaribagh tannery industrial area Mondol et al.(11) observed an elevated level of nitrogen in the range of 1.25 to $2.47 \%$. The total nitrogen analyzed in this study were below the optimum range of 0.271 to $0.36 \%$ according to Farid et al. (34).

The total phosphorus concentration varied from 0.090 to $0.145 \%$ in the top-soils and 0.086 to $0.193 \%$ in the sub-soils (Table 4 ). The higher concentrations of total phosphorus were found due to the use of various phosphate salts in the tanning processes. Similarly, a higher concentration of P measured by Mondol et al. ${ }^{(11)}$ in the range of 0.154 to $0.690 \%$.

The concentration of total potassium ranged from 0.117 to $0.409 \%$ in topsoils and 0.117 to $0.479 \%$ in subsoils (Table 4 ). The highest concentrations were in the topsoil of SSP-6 an agricultural field. The high concentration might be due to the fertilizer application. The total $\mathrm{K}$ recorded in this study were in an accordance with the results reported by Mondol et al.(11) in the Hazaribagh area. The concentration of total sulfur ranged from 0.080 to $0.870 \%$ in topsoils and 0.106 to $0.416 \%$ in subsoils. The highest concentration was recorded in UWP $(0.416 \%)$ which was collected from untreated wastewater pond. The higher concentration might be due to the wastes containing sulfur salts dumped into that pond ${ }^{(11)}$. Mondol et al.(11) found a lower total sulfur concentration in the range of 0.065 to $0.185 \%$, compared to this current finding.

Nutrient concentrations of the collected plant samples: The maximum phosphorus concentration was found in the root of PSP-3 $(0.08 \%)$ and the highest concentration in the leaf sample of PSP-7 (0.838\%) (Table 4). The standard limit of P in plant $(0.1 \text { to } 0.4 \%)^{(34)}$. The mean concentration of $\mathrm{P}$ in every plant samples are within the standard limit, so there was no P deficiency in plant samples. 
Table 5. Status of total N, P, K, S of the studied plant samples around Hemayetpur area.

\begin{tabular}{|c|c|c|c|c|c|c|}
\hline \multirow{2}{*}{$\begin{array}{l}\text { Denota- } \\
\text { tion }\end{array}$} & \multirow[t]{2}{*}{ Plant species } & \multirow{2}{*}{$\begin{array}{l}\text { Plant } \\
\text { parts }\end{array}$} & \multicolumn{4}{|c|}{ Major nutrients (\%) } \\
\hline & & & Phosphorus & Potassium & Sulfur & Nitrogen \\
\hline \multirow[t]{3}{*}{ PSP-1 } & Napier Grass & Root & $0.198 \pm 0.02$ & $0.472 \pm 0.071$ & $0.174 \pm 0.034$ & $0.236 \pm 0.019$ \\
\hline & \multirow{2}{*}{$\begin{array}{l}\text { (Pennisetum } \\
\text { purpureum) }\end{array}$} & Shoot & $0.160 \pm 0.005$ & $0.506 \pm 0.118$ & $0.217 \pm 0.015$ & $0.295 \pm 0.024$ \\
\hline & & Leaf & $0.444 \pm 0.045$ & $1.825 \pm 0.236$ & $0.712 \pm 0.137$ & $0.977 \pm 0.118$ \\
\hline \multirow[t]{3}{*}{ PSP-2 } & \multirow{3}{*}{$\begin{array}{l}\text { Napier Grass } \\
\text { (Pennisetum } \\
\text { purpureum) }\end{array}$} & Root & $0.379 \pm 0.004$ & $3.644 \pm 0.024$ & $0.799 \pm 0.012$ & $1.283 \pm 0.071$ \\
\hline & & Shoot & $0.349 \pm 0.007$ & $4.045 \pm 0.071$ & $0.497 \pm 0.058$ & $0.675 \pm 0.047$ \\
\hline & & Leaf & $0.446 \pm 0.056$ & $3.745 \pm 0.071$ & $0.420 \pm 0.045$ & $0.571 \pm 0.019$ \\
\hline \multirow[t]{3}{*}{ PSP-3 } & \multirow{3}{*}{$\begin{array}{l}\text { Water hyacinth } \\
\text { (Eichhornia } \\
\text { crassipes) }\end{array}$} & Root & $0.080 \pm 0.005$ & $1.424 \pm 0.283$ & $0.824 \pm 0.023$ & $1.319 \pm 0.046$ \\
\hline & & Shoot & $0.115 \pm 0.014$ & $0.957 \pm 0.189$ & $0.340 \pm 0.048$ & $0.462 \pm 0.014$ \\
\hline & & Leaf & $0.062 \pm 0.002$ & $1.190 \pm 0.000$ & $0.958 \pm 0.066$ & $1.543 \pm 0.056$ \\
\hline \multirow[t]{3}{*}{ PSP-4 } & \multirow{3}{*}{$\begin{array}{l}\text { Taro (Colocasia } \\
\text { esculenta) }\end{array}$} & Root & $0.354 \pm 0.01$ & $1.992 \pm 0.567$ & $0.302 \pm 0.016$ & $0.411 \pm 0.048$ \\
\hline & & Shoot & $0.369 \pm 0.033$ & $3.544 \pm 0.118$ & $0.037 \pm 0.011$ & $0.061 \pm 0.034$ \\
\hline & & Leaf & $0.837 \pm 0.041$ & $2.977 \pm 0.165$ & $1.014 \pm 0.046$ & $1.750 \pm 0.189$ \\
\hline \multirow[t]{3}{*}{ PSP-5 } & \multirow{3}{*}{$\begin{array}{l}\text { Water spinach } \\
\text { (Ipomoea } \\
\text { aquatica) }\end{array}$} & Root & $0.087 \pm 0.008$ & $0.155 \pm 0.047$ & $0.285 \pm 0.007$ & $0.388 \pm 0.118$ \\
\hline & & Shoot & $0.214 \pm 0.029$ & $3.995 \pm 0.331$ & $0.315 \pm 0.064$ & $0.429 \pm 0.0259$ \\
\hline & & Leaf & $0.502 \pm 0.034$ & $3.678 \pm 0.826$ & $0.533 \pm 0.018$ & $0.726 \pm 0.025$ \\
\hline \multirow[t]{3}{*}{ PSP-6 } & \multirow{3}{*}{$\begin{array}{l}\text { Napier Grass } \\
\text { (Pennisetum } \\
\text { purpureum) }\end{array}$} & Root & $0.328 \pm 0.046$ & $0.255 \pm 0.047$ & $0.219 \pm 0.028$ & $0.297 \pm 0.035$ \\
\hline & & Shoot & $0.202 \pm 0.019$ & $0.84 \pm 0.118$ & $0.178 \pm 0.048$ & $0.241 \pm 0.036$ \\
\hline & & Leaf & $0.784 \pm 0.030$ & $2.092 \pm 0.094$ & $0.531 \pm 0.024$ & $0.728 \pm 0.041$ \\
\hline \multirow[t]{3}{*}{ PSP-7 } & \multirow{3}{*}{$\begin{array}{l}\text { Napier Grass } \\
\text { (Pennisetum } \\
\text { purpureum) }\end{array}$} & Root & $0.538 \pm 0.025$ & $0.072 \pm 0.071$ & $0.163 \pm 0.021$ & $0.215 \pm 0.004$ \\
\hline & & Shoot & $0.144 \pm 0.004$ & $0.155 \pm 0.000$ & $0.034 \pm 0.01$ & $0.045 \pm 0.002$ \\
\hline & & Leaf & $0.838 \pm 0.053$ & $1.174 \pm 0.732$ & $0.359 \pm 0.052$ & $0.474 \pm 0.047$ \\
\hline \multirow[t]{3}{*}{ CPS } & \multirow{3}{*}{$\begin{array}{l}\text { Scutch grass } \\
\text { (Cynodon } \\
\text { dactylon) }\end{array}$} & Root & $0.446 \pm 0.047$ & $0.155 \pm 0.047$ & $0.346 \pm 0.035$ & $0.457 \pm 0.014$ \\
\hline & & Shoot & $0.121 \pm 0.051$ & $0.973 \pm 0.259$ & $0.907 \pm 0.190$ & $1.198 \pm 0.214$ \\
\hline & & Leaf & $0.315 \pm 0.053$ & $0.890 \pm 0.283$ & $0.379 \pm 0.036$ & $0.501 \pm 0.087$ \\
\hline
\end{tabular}

The nitrogen concentrations in plant samples ranged from 0.045 to $1.75 \%$ (Table 4 ). The highest concentration was observed in PSP-4. However, the nitrogen concentrations of the plant samples were within the optimum level. The potassium concentrations of plant sample ranged from 0.072 to $4.045 \%$. The highest concentration of potassium $(4.045 \%)$ was observed in the shoot sample of PSP-2 which was collected just $100 \mathrm{~m}$ away from the discharge pipe. The high concentrations might be associated with the uptake of 
salt that released from the discharge pipes. The optimum concentration of potassium in plant samples is 1 to $4 \%{ }^{(34)}$. The study revealed that most of the samples had the concentration within the optimum range. The concentrations of sulfur in plant samples ranged from 0.034 to $1.014 \%$ concerning distance and plant parts. Leaf samples had a higher level of sulfur compared to root and shoot. Besides, samples adjacent to the discharge point exhibited a higher concentration of sulfur than the upstream samples and the concentration gradually decreased as the distance increased. The studied samples showed concentrations within the standard level.

Correlation study: In topsoil the available nitrogen and total sulfur showed a significant positive correlation with EC which suggested that the sulfur and nitrogen might come from the similar source in soil. A positive correlation was also observed between available potassium and total potassium. Total sulfur showed a positive correlation with available nitrogen and available phosphorus which were significant as well (Table 6). These relations might indicate that the sources and the characteristics of the nutrients of the corresponded specimens might be similar.

Table 6. Correlation matrix between available and total nutrients with the physicochemical properties of top soils.

\begin{tabular}{lcccccccccc}
\hline Properties & AN & TN & AK & TK & AP & TP & AS & TS & PH & OC \\
\hline TN & 0.452 & & & & & & & & & \\
AK & 0.134 & 0.032 & & & & & & & & \\
TK & 0.169 & 0.039 & $0.820^{*}$ & & & & & & & \\
AP & 0.753 & 0.003 & -0.156 & -0.199 & & & & & & \\
TP & -0.324 & -0.225 & 0.418 & 0.608 & -0.686 & & & & & \\
AS & 0.263 & 0.086 & 0.007 & -0.524 & 0.466 & -0.641 & & & & \\
TS & $0.987^{* *}$ & 0.505 & 0.073 & 0.056 & $0.780^{*}$ & -0.422 & 0.365 & & & \\
pH & 0.222 & -0.709 & -0.108 & -0.105 & 0.698 & -0.285 & 0.201 & 0.194 & & \\
OC & -0.442 & 0.184 & 0.232 & 0.421 & $-0.770^{*}$ & 0.466 & -0.590 & -0.516 & -0.651 & \\
EC & $0.831^{*}$ & 0.251 & 0.605 & 0.488 & 0.559 & -0.122 & 0.308 & $0.781^{*}$ & 0.228 & -0.220 \\
\hline
\end{tabular}

${ }^{* *}$ Correlation is significant at the $0.01 \%$ level (2-tailed), ${ }^{*}$ Correlation is significant at the $0.01 \%$ level (2 - tailed). AN - Available Nitrogen; TN - Total Nitrogen; AK - available Potassium; TK - total potassium; AP - available phosphorus; TP - total phosphorus; AS- available sulfur; TS-total sulfur; OC- organic carbon; EC- electrical conductivity.

In subsoil, organic carbon showed a positive significant correlation with total nitrogen and total sulfur whereas a negative correlation was observed between total nitrogen and $\mathrm{pH}$ (Table 7). 
Table 7. Correlation matrix between available and total nutrients with the physicochemical properties of subsoil.

\begin{tabular}{lcccccccccc}
\hline & AN & TN & AK & TK & AP & TP & AS & TS & PH & OC \\
\hline TN & 0.490 & & & & & & & & & \\
AK & 0.541 & 0.369 & & & & & & & & \\
TK & -0.575 & -0.038 & -0.650 & & & & & & & \\
AP & -0.733 & -0.745 & $-0.851^{*}$ & 0.430 & & & & & & \\
TP & 0.343 & -0.153 & $0.828^{*}$ & -0.509 & -0.526 & & & & & \\
AS & 0.129 & 0.595 & 0.540 & -0.018 & -0.542 & 0.231 & & & & \\
TS & 0.260 & $0.841^{*}$ & -0.019 & 0.244 & -0.460 & -0.441 & 0.148 & & & \\
PH & -0.726 & $-0.876^{*}$ & -0.675 & 0.479 & $0.911^{*}$ & -0.196 & -0.469 & -0.646 & & \\
OC & 0.301 & $0.947^{* *}$ & 0.096 & 0.144 & -0.499 & -0.428 & 0.575 & $0.833^{*}$ & -0.703 & \\
EC & 0.308 & 0.165 & 0.356 & -0.047 & -0.286 & 0.347 & 0.724 & -0.306 & -0.110 & 0.163 \\
\hline
\end{tabular}

The statistical analysis between these parameters showed a positive correlation between DO and TDS $(r=1.000)$ which was significant at $1 \%$ level. The study also indicated a negative correlation between TDS and DO $(r=-0.734)$; EC and DO $(r=-0.735)$ where both were significant at $5 \%$ level (Table 8 ).

Table 8. Correlation matrix between the water quality parameters.

\begin{tabular}{lccccccc}
\hline Properties & $\mathrm{pH}$ & $\mathrm{EC}$ & $\mathrm{TDS}$ & $\mathrm{DO}$ & $\mathrm{N}$ & $\mathrm{P}$ & $\mathrm{K}$ \\
\hline EC & 0.063 & & & & & & \\
TDS & 0.064 & $1.000^{* *}$ & & & & & \\
$\mathrm{DO}$ & -0.329 & $-0.716^{*}$ & $-0.715^{*}$ & & & & \\
$\mathrm{~N}$ & 0.097 & $0.979^{* *}$ & $0.979^{* *}$ & $-0.675^{*}$ & & & \\
P & 0.113 & $0.891^{* *}$ & $0.896^{* *}$ & $-0.623^{*}$ & $0.871^{* *}$ & & \\
$\mathrm{~K}$ & -0.021 & $0.911^{* *}$ & $0.916^{* *}$ & -0.582 & $0.873^{* *}$ & $0.970^{* *}$ & \\
$\mathrm{~S}$ & -0.145 & $0.960^{* *}$ & $0.961^{* *}$ & -0.587 & $0.952^{* *}$ & $0.895^{* *}$ & $0.933^{* *}$ \\
\hline
\end{tabular}

${ }^{* *}$ Correlation is significant at the $0.01 \%$ level (2-tailed); ${ }^{*}$ Correlation is significant at the $0.05 \%$ level (2-tailed).

This study revealed that almost all the water quality parameters exceeded the WHO standard critical limits that is indicating degraded quality of tannery adjacent Dhaleshwari river water. Nutrient concentrations in soil and plant suggested that soils contained deficient or excess amount of some nutrients but plants did not show any 
nutrient deficiency. An elevated level of sulfur was found in the soil samples. The correlation shows that sulfur has positive correlation with phosphorus and nitrogen, implying similar sources and characteristics of the corresponding nutrients. It can be said that if the degree of environmental quality degradation continues, in near future the adjacent environment of tannery industrial area might get threatened for surrounding environment. Therefore, the authority should monitor wastewater treatment according to the WHO/DOE standard before discharging them into the river.

\section{References}

1. Bhuiyan MAH, NI Suruvi, SB Dampare, MA Islam, SB Quraishi, S Ganyaglo and S Suzuki 2011. Investigation of the possible sources of heavy metal contamination in lagoon and canal water in the tannery industrial area in Dhaka, Bangladesh. Environ. Monit. Assess. 175(14): 633-649.

2. Deepali KK and Gangwar 2010. Metals concentration in textile and tannery effluents, associated soils and ground water. NY Sci. J. 3(4): 82-89.

3. Sinha S, R Saxena and S Singh 2002. Comparative studies on accumulation of Cr from metal solution and tannery effluent under repeated metal exposure by aquatic plants: its toxic effects. Environ. Monit. Assess. 80(1): 17-31.

4. Huq I 1998. Critical environmental issues relating to tanning industries in Bangladesh. In: Naidu et al. (eds.). Towards Better Management of Soils Contaminated with Tannery waste. The Proceedings of a workshop, Tamil Nadu Agricultural University, Coimbatore, India.p. 5.

5. Sahu RK, S Katiyar, J Tiwari and GC Kisku 2007. Assessment of drain water receiving effluent from tanneries and its impact on soil and plants with particular emphasis on bioaccumulation of heavy metals. J. Environ. Biol. 28(3): 685-690.

6. Raj EM, DP Sankaran, SK Sreenath, S Kumaran and N Mohan 1996. Studies on treated effluent characteristics of a few tanneries at Crompet, Madras. Indian. J. Environ. Protect. 16: 252254.

7. Ahmed MK, S Ahamed, S Rahman, MR Haque, and MM Islam 2009. Heavy metals concentration in water, sediments and their bioaccumulation in some freshwater fishes and mussel in Dhaleshwari River, Bangladesh. Terr. Aquat. Environ. Toxicol. 3: 33-41.

8. Arshad M, AN Chaudhry, G Shaheer, S Farroq, S Manzoor and A Reza 2018. Effect of waste physico-chemical properties on decomposition rates and nutrients release during composting. Int. J. Biosci. 12(1): 330-337.

9. Alvarez-Bernal D, SM Contreras-Ramos, N Trujillo-Tapia, V Olalde-Portugal, JT FríasHernández and L Dendooven 2006. Effects of tanneries wastewater on chemical and biological soil characteristics. Appl. Soil Ecol. 33(3): 269-277.

10. Elahi SF, AS Chamon, B Faiz, MN Mondol and MH Rahaman 2010. Specification of heavy metals in soils, plants and water in Bangladesh. Bangladesh Journal of Agriculture and Environment 5(2): 79-97.

11. Mondol MN, A Asia, AS Chamon and Faiz SMA 2017. Contamination of Soil and Plant by the Hazaribagh Tannery Industries. J. Asiat. Soc. Bangladesh Sci. 43(2): 207-222. 
12. Uddin MJ, S Khanom, S Mamun and Z Parveen 2016. Effects of irrigation water on some vegetables around industrial areas of Dhaka. Bangladesh J. Scientific Res. 28(2): 151-159.

13. BARC 1999. Bangladesh Agricultural Research Centre. Fertilizer recommendation guide. Farmgate, New Airport Road, Dhaka-1215. pp. 270.

14. APHA 1998. Standard Methods for the examination of water and waste water American Public Health Association. pp. 874.

15. Jackson, AP and BJ Alloways 1962. The transfer of Cd from agricultural soils to the human food chain in Biogeochemistry of Trace Metals. Advances in Trace Substances Research. D.C. Adriano, Ed. (Boca Raton: CRC press Inc.). pp. 109-158.

16. Blum WEH, H Spiegel and WW Wenzel 1996. BODENZUSTANDSINVENTUR-Konzeption, Durchfuhrung und Bewertung. Bundesministerium fur Land- und Forstwirtschaft.Inst. für Bodenforschung, Univ. Für Bodenkultur, Vienna, 2nd edition: 102.

17. Bremner JM and DR Keeney 1966. Determination and isotope-ratio analysis of different forms of nitrogen in soils. 3. Exchangeable 'ammonium, nitrate, and nitrite' by extraction distillation methods. Soil Sci. Soc. Am. Proc. 30: 577-582.

18. Watanabe FS and SR Olsen 1965. Test of an ascorbic acid method for determining phosphorus in water and NaHCO3 extracts from soil. Soil Sci. Soc. Am. J. 29(6): 677-678.

19. Yoshida S, DA Forno, JH Cock and KA Gomez 1976. Laboratory manual for physiological study of rice. 3rd ed. Los Banõs (Philippines): International Rice Research Institute.

20. Marr IL and MS Cresser 1983. Environmental Chemical Analysis. International Textbook Company, New York.

21. Sinclair AG 1973. An 'Autoanalyzer' method for determination of extractable sulphate in soil. New Zealand J. Agric. Res. 16(2): 287-292.

22. Walkley A and IA Black 1934. An examination of the Degtjareff method for determining soil organic matter, and a proposed modification of the chromic acid titration method. Soil Sci. 37(1): 29-38.

23. Parveen S, R Bharose and D Singh 2017. Assessment of Physico-Chemical Properties of Tannery Waste Water and Its Impact on Fresh Water Quality. Int. J. Curr. Microbiol. Appl. Sci. 6(4): 1879-1887.

24. Asghar MZ, A Arshad, L Hong, M Riaz and M Arfan 2018. Comparative assessment of physicochemical parameters of waste water effluents from different industries in Lahore, Pakistan. Proc. Int. Acad. Ecol. Environ. Sci. 8(2): 99-112.

25. WHO (World Health Organization) 2002. Water pollutants: Biological agents, Dissolved chemicals, Non dissolved chemicals, Sediments, Heat, WHO CEHA, Amman, Jordan.

26. Murali SA, S. Henciya and P Malliga 2013. Bioremediation of tannery effluent using fresh water cyanobacterium Oscillatoria annae with coir pith. Int. J. Environ. Sci. 3(6): 1881-1890.

27. Hoque M and P Deb 2017. Assessment of Physicochemical Water Quality Parameters and Heavy Metals Concentration in Water Samples from Buriganga River Adjacent to Dhaka City. J. environ. sci. nat. resour. 9(2): 97-104.

28. Siddiqee MH, MS Islam and MM Rahman 2013. Assessment of pollution caused by tannerywaste and its impact on aquatic bacterial community in Hajaribag, Dhaka. Stamford J. Microbiol. 2(1): 20-23. 
29. Kaushik A, A Kansal, Santosh, Meena, S Kumari and CP Kaushik 2009. Heavy metal contamination of river Yamuna, Haryana, India: Assessment by Metal Enrichment Factor of the Sediments. J. Hazard. Mater. 164(1): 265-270.

30. Gutterres M, J Benvenuti, JT Fontoura and S Ortiz-Monsalve 2015. Characterization of raw wastewater from tanneries. J. Soc. Leath. Tech. Ch. 99(6): 280-287.

31. UNIDO (United Nations Industrial Development Organization) 2000. Regional program for pollution control in the tanning industry in South East Asia: Chrome balance in leather processing.

32. Ponnamperuma FNN 1985. Chemical kinetics of Wet Land Rice Soils Relative to Soil Fertility. In wetland soils: Characterizations, Classification and Agriculture, IRRI, Philippine.

33. Piao HC, GS Liu, YY Wu and WB Xu 2001. Relationships of soil microbial biomass carbon and organic carbon with environmental parameters in mountainous soils of southwest China. Biol. Fertil. Soils 33(4): 347-350.

34. Farid ATM, MAM Miah, M Jahiruddin, SMK Rahman and MA Quayyum 2005. Fertilizer Recommendation Guide. Bangladesh Agricultural Research Council. Farmgate, Dhaka. 206. 